\title{
The Impact of COVID-19: A Comparative Study of the Melbourne and Sydney Jewish Communities
}

\author{
Suzanne D. Rutland ${ }^{1}$ (1)
}

Received: 2 November 2020 / Accepted: 18 July 2021 / Published online: 7 September 2021

(c) Crown 2021

\begin{abstract}
Compared to other parts of the Jewish world, Australia has handled the COVID-19 situation well, going into full lockdown early, with fewer deaths on a population basis. At the same time, there were significant differences in terms of the impact of the second wave of the pandemic in Melbourne and Sydney. This qualitative study examines how these two major Jewish centers, where $84 \%$ of the Jews in Australia reside, responded to the COVID-19 pandemic in 2020. It will discuss the policies that were put in place to assist those in need, with a range of different activities, including Jewish schools, going on-line, leading to many more opportunities to access news and participate in learning sessions. This study will highlight the similarities and differences between the two centers in terms of their organizational structures, which developed out of different historical migration patterns, and how these impacted on the current responses to the pandemic. The Sydney Jewish community has a centralized system of fundraising, planning and management in contrast to Melbourne, where the challenging situation created the need for better coordination. This was spearheaded by Jewish Care Victoria, which subsequently argued for a more permanent system of coordinated fundraising, planning and management for Melbourne Jewry. This article, which examines these developments, is based on oral interviews, written communications, community and media commentary, as well as historical material. As the Melbourne-based editor of The Australian Jewish News, Zeddy Lawrence, commented, "the community did not decline but thrived," indicating its "resourcefulness," but it remains to be seen if this has any long-term impact on the community structure of Melbourne Jewry.
\end{abstract}

Keywords COVID-19 · Australian Jewry · Organizational structure · UltraOrthodox $\cdot$ Aged-care $\cdot$ Antisemitism

Suzanne D. Rutland

Suzanne.rutland@sydney.edu.au

1 Department of Hebrew, Biblical and Jewish Studies, School of Languages and Cultures, A18,

University of Sydney, Sydney 2006, Australia 


\section{Introduction}

In comparison with many other countries, Australia has managed to respond effectively to the pandemic, which caught the world by surprise. The federal government isolated the continent quickly with extremely strict quarantine policies, and the country went into early lockdown starting on 16 March 2020 (Victorian Parliamentary Inquiry 2020). As a result, from mid-March 2020 to late April 2021 Australia's cumulative mortality rate was 3.9 excess deaths per 100,000 in the population, much lower than other Diaspora Jewish centers- the United Kingdom ranks 13th in the John Hopkins University's mortality hierarchy with excess deaths of 191.02 per 1,00,000; the United States with 174.24 and France 154.21 (https://coronavirus.jhu.edu/data/mortality). The federal Liberal Party government (despite the name "Liberal," this is a conservative political party) responded by establishing a National Cabinet to deal with the pandemic, and enumerating four stages of response, with the fourth stage requiring full "lockdown," that is, requiring all citizens to remain at home, apart from specified reasons, such as the need to seek medical assistance or testing, exercise, and working in specified areas. Led by Prime Minister Scott Morrison and Treasurer Joshua Frydenberg, the federal government introduced generous packages through the "JobKeeper" program (a wage subsidy program designed to keep business open so that people can retain their jobs), and "JobSeeker" (payments to assist those who had lost their jobs and were looking for work) to help businesses and employees to weather the financial storm.

However, with the onset of the second wave, there has been a striking difference between the situation in the states of Victoria and New South Wales, so that from the start of the pandemic until mid-April 2021, Victoria has experienced 820 of the 910 deaths and New South Wales only 54 deaths by mid-April 2021 (Australian government, Department of Health). This difference was because the administration of government health systems is state-based, and there are differences in the way the Victorian and New South Wales health systems have been managed. The Victorian health system is more centralized than New South Wales, and since the 1990s has been under-resourced, so it was less able to develop an effective contact tracing system, vital for effectively containing the spread of the virus (Swan and McIntrye October 15, 2020).

The Australian Jewish population is 117,903 , with 54,735 in Melbourne, the capital of Victoria, and 47,800 in Sydney, the capital of New South Wales, constituting $84 \%$ of the Jews in Australia (Graham and Narunsky 2020). These two major Jewish communities were faced with different local situations. Given this fact, this article will explore the impact of COVID-19 on these two major centers, Sydney and Melbourne, and analyze the similarities and differences in their responses. It will argue that the historical differences between the two Jewish communities, in terms of their ethnic composition and community structures, continue to contribute to the differences in their responses. These were also impacted by the significant differences between the two centers in terms of the state government policies and the much higher mortality rates in Victoria, so that 
a major factor in the different situations facing the two largest Australian Jewish communities was a result of the difference in the state government health structures as discussed above.

In general, writing contemporary history is challenging and this is the case with the present pandemic. Currently it is not clear how long the pandemic will take to come under control. How long will the vaccination programs take to enable life to return to normal, and will the mutations lead to additional lockdown periods? What will the long-term effects of the pandemic be in terms of the economy and health issues, both physical and mental? To what extent will young people, whose schooling has been disrupted, be affected in the long term, especially if there is increased unemployment? How will traditional synagogue services and institutional structures be affected by the long-term effects of the pandemic? These are questions that other studies on the impact of COVID 19 have also investigated, particularly those by Nishma $(2020,2021)$ and Brandeis (Saxe and Aronson 2020) in the United States and the UK Jewish Policy and Research Institute (JPR) study (2020), because the impact on the pandemic on Jewish life in the Diaspora is a global issue.

\section{Impact of COVID 19 in Other Parts of the Jewish World}

Several quantitative and qualitative studies have been undertaken on the impact of COVID-19 on other Jewish communities, most noticeably in the United States and United Kingdom. The United Kingdom was in the forefront of research with the Office for National Statistics (ONS) undertaking research published in June 2020, which examined heightened mortality rates among Black, Asian and minority ethnic (BAME) groups, including the Jewish community. The British-based JPR supplemented these findings with two short reports drawing on additional data, as well as undertaking an additional survey in July 2020. In December 2020, the JPR released a major comparative study of excess mortality rates in the main Jewish communities across the world between March and May 2020, focusing on specific cities and examining their contexts. They obtained the data from the Jewish burial societies for the Jewish population, and from EUROSTAT (European Statistical Office) or national statistical offices for the non-Jews to compare Jews and non-Jews living in the same city or region, and to ascertain what the authors describe as a "Jewish penalty"; that is, the Jewish mortality rate was higher than the non-Jewish rate. The study found that in the three largest European Jewish communities, the United Kingdom, France, and Germany, there were very different results: in Britain for the Jewish community in London and its environs there was a high level of excess morality, with the levels of Jewish mortality being 3.7 times higher than normal; in France it was twice as high, and in Germany very close to normal (p. 17). The researchers then sought to classify other Jewish communities within these three categories.

The study also found that not only were there variations between countries, but there was a spectrum even within countries between the different localities. For example, in Paris the excess morality was only slightly higher, but in Strasbourg it was relatively high. In addition, there were differences in the timing of the levels of high mortality, due to the differences in the sizes of the Jewish and non-Jewish 
populations. In London, for example, the highest level of mortality was fairly early after the start of the pandemic in April, probably due to the smaller population and more homogenous nature of the Jewish community, resulting in the virus spreading more quickly. This spectrum was also found outside Europe. Thus, New York had a significantly lower level of mortality than the general population, even though it was still high, while Florida experienced a slightly higher level (p. 22). In contrast, Toronto, Montreal, and Florida represented the "French pattern." In New York, while the levels of excess mortality represented the worst trends, as in Britain, there was no Jewish penalty.

In an additional study, Staetsky (2021) further examined the issue of a "Jewish penalty" in Britain and clearly demonstrated that the excess mortality rate for men was twice the average of British Christians and 1.2 times the average for women. In both his report and article, an effort was made to try to analyze the reasons for this higher British Jewish mortality rate, with the factors of age, health structure, and social patterns, including that of the haredi (ultra-Orthodox) population, but no clear factor has emerged. This has highlighted the need for further research.

In the United States, studies have been carried out by the Nishma Foundation and Brandeis University. These studies focused more on the impact from the Jewish community and individual perspectives. The Nishma study (2020 and 2021) found significant differences between the different strands of Judaism, with the incidence of COVID-19 reported only by $7 \%$ of non-Orthodox respondents, while $57 \%$ of the Hasidic Jews surveyed reported the incidence of the coronavirus. Interestingly, when it came to the perceived threat of the pandemic, a smaller percentage of the Hasidic Jews saw it as a major threat and were less likely to take preventative measures, including support for the vaccination program (Nishma 2021).

Both American studies found that many of those surveyed were affected by the isolation of the extended lockdown periods, that the situation of those struggling financially before the pandemic was exacerbated by the pandemic, and that the younger generation were more severely affected both financially and socially, and this affected their mental health. Online services and learning programs sought to overcome these problems, but the Brandeis survey found that it was those who were most engaged before the pandemic who used these options. The majority who participated in the online programs said they would continue to use these after the pandemic (Saxe and Aronson 2020).

These studies all stress the importance of research to better understand the impact of COVID-19, but to date no wide-scale quantitative research has been undertaken for the Australian Jewish communities in either Sydney or Melbourne. Staetsky and Paltiel (December 2020) did use the figures from the Melbourne Jewish burial societies and found that the Melbourne Jewish community had a slightly lower mortality level than the Australian average. As they noted: "Given that Sydney and Melbourne account for the majority of Jews in Australia, we can confidently conclude that this population was impacted very lightly, if at all, by coronavirus mortality" (p. 22). They argue that until May, both Israel and Australia followed what they called the "German pattern" in the European context. The historical background of these two 
major Jewish centers helps to provide context in terms of the overall Australian pattern and the Jewish responses to the pandemic in both cities.

\section{A Tale of Two Cities: Differing Ethnic Composition and Community Structure}

Starting in the nineteenth century and reinforced throughout the twentieth century, Melbourne and Sydney experienced differing ethnic migration patterns which have influenced the nature and structures of both cities. Since 1945, no matter what index of Jewish identification and communal commitment one selects, Melbourne Jewry has always registered on a much higher level. This has held true for Jewish day school attendance, Yiddish culture, funds raised for Israel, participants in long-term youth leadership programs in Israel, and the number of haredi Jews including students in yeshivot. A recent study of Melbourne Jewry and its educational structure has highlighted these differences (Markus, Munz and Munz 2020).

Several factors account for these differences. An important one is the pattern of immigration. After 1945, Melbourne Jewry attracted a much higher proportion of Polish Jewish Holocaust survivors, while Sydney, as a more cosmopolitan city, attracted more assimilated survivors from Central Europe-countries such as Germany, Austria, and especially Hungary. These immigration trends produced institutional differences. While Melbourne Jewry had about 20 Landsmannschaften (organizations of former residents of various towns and cities in Poland and Ukraine), with a Federation of Landsmannschaften, Sydney Jewry had none. The spectrum of Jewish day schools in Melbourne reflects the wide range of Jewish identification in interwar Poland. Other historical and local conditions help account for the differences. Jewish life in nineteenth-century Melbourne was already more diverse. This was because Melbourne was founded later, and by free settlers, so that the community there "seemed to have begun on a higher Jewish note and attracted more of the intensely Jewish immigrants and ministers from the start" (Rutland 2005, p. 153). Melbourne's history of higher church attendance and its stronger intellectual traditions were also important factors. Geography also played a role: differing climates, with Sydney's warmer temperatures and Melbourne's colder climate, inevitably result in differing lifestyle possibilities and choices in the two cities.

The recent narrowing of the gap between the two communities can be seen in a number of areas. Only $17 \%$ of Jewish children attended Jewish day schools in Sydney in 1970, compared to over 50\% in Melbourne. Today, the figures are $50 \%$ in Sydney and $60 \%$ in Melbourne, with the percentage higher in high schools. Melbourne traditionally raised double the amount raised in Sydney for the United Israel Appeal (UIA) and emergency Zionist campaigns, even though the difference in the size of the two communities is not great. Yet, from the mid-1990s this changed dramatically, and Sydney now raises almost the same amount as Melbourne.

The fabric of Sydney's Jewish life has strengthened recently for several reasons. In Melbourne, there is no central communal fundraising organization, making joint communal and long-term planning difficult, while in Sydney a coordinated fundraising body, the Jewish Communal Appeal (JCA), also undertakes communal planning. 
The JCA was formed after the Six-Day War in 1967, when local fundraising was disrupted by a decision to hold an emergency UIA. It is similar to the America federation system, but its brief is more limited as fundraising for Israel is done separately through the UIA and the Jewish National Fund (JNF) which, with other Zionist organizations, operate under the umbrella of the Zionist Federation of Australia (ZFA). While initially the JCA struggled to achieve communal acceptance, the picture has changed significantly in recent years. A young, dynamic leadership group has taken the organization to higher levels of communal giving. The JCA has given the community a new sense of unity, and the rigorous processes of its allocation committee have allowed for more logical planning in the use of community funds. Partly because of its more predictable funding base, the community's umbrella body is far stronger and more effective in maintaining communal discipline than its Melbourne counterpart. Another major consideration is that South African Jews have injected energy into Sydney's Jewish life, not just in numbers but also in terms of Jewish commitment. Yet, even though over the last two decades Sydney Jewry has strengthened its communal structures, and the gap has narrowed, Melbourne is still the more dynamic Jewish center as illustrated by the latest in-depth communal study, GEN17, even though the Melbourne community experiences more difficulties in terms of communal cohesion, facing stronger internal divisions (Graham and Markus 2018).

\section{Current Australian Demographic Studies}

The differences between the two communities have been highlighted by the recent GEN17 study (Graham and Markus 2018). GEN17 was a nationwide survey which covered a wide range of topics relating to Jewish life and identity in Australia, conducted jointly by Dr. David Graham of Sydney's JCA and Professor Andrew Markus of Melbourne's Australian Centre for Jewish Civilisation at Monash University. There was a total of 8621 responses which the authors argue is "an enormous number when compared with a number of international studies" (Graham and Markus 2018 , p. 8). These findings, combined with the most recent census data from 2016, enable demographers to provide a clear picture of developments within Australian Jewry.

According to the 2016 census Sydney's Jewish population was 47,078, constituting $40.5 \%$ of the total Australian Jewish population and $95 \%$ of the state's population living there (Graham and Narunsky 2019). Melbourne's Jewish population was 53,824 constituting $46 \%$. As can be seen, Melbourne's Jewish population is over $15 \%$ larger than Sydney's, but Melbourne's Jewish school enrollments are 50\% higher than Sydney's. In addition, a much higher percentage of Melbourne parents with children under the age of five are planning to send their child to a Jewish school-48\% compared with 19\% — and there is a similar difference with parents of a 12-year-old child- $43 \%$ compared with 20\% (Markus, Munz and Munz 2020, 45). The demographic profile is also different, with $48 \%$ being Australian born in Sydney compared with Melbourne's 57\%; more South Africans in Sydney-19\%—compared with Melbourne's 8\%; more Former Soviet Union Jews in Melbourne, 10\% compared to Sydney's 6\%; and more 
Israelis in Melbourne, 7\% compared to Sydney's 5\% (Markus and Graham 2018, 11). These differences have influenced the way these two main Australian Jewish communities responded to COVID-19.

In further investigating the Australian responses, this article uses a qualitative research methodology to supplement the JPR findings, to shed light on communal responses to COVID-19 in the two major Australian Jewish communities and to examine the similarities and differences between the two centers.

\section{Methodology}

To date there has been no quantitative survey or major publication dealing with the issue of COVID-19 in Australia, and given the time and funding limitations it has not been possible to implement a full-scale qualitative study. Rather, this study is based on a range of sources, including historical, media, social media and information that was distributed to community members in both Sydney and Melbourne, as well as the reflections of some key community leaders in both cities through the pages of the Jewish press. This material was gathered from the start of the pandemic in March 2019 until October 2019.

Thanks to the organized structure of the community in both cities, there is a surfeit of information from these sources. For example, the Victorian Jewish Community COVID-19 Taskforce sent out around 40 bulletins updating Victorian Jewry of state government requirements, informing members of the support services available through the Jewish institutions, and ensuring that there was a proper safety net for all members during the second wave of the lockdown in that city. The issue was also covered in the Jewish press, through both the online publications of J-Wire and Plus61J, and The Australian Jewish News, the major Jewish paper published with Melbourne and Sydney editions.

In addition, 12 key stakeholders from both Melbourne and Sydney agreed to contribute to the study, including three key journalists, the CEOs of Jewish Care in both cities, two community professionals, three key lay leaders and one community figure, six of whom agreed to a Zoom interview and six emailed their responses. The interviewees were chosen based on their close involvement with all issues relating to the Jewish response to the pandemic. These interviews were conducted in October 2020.

Thus, this early study of COVID-19 and Australian Jewry can provide some insights into the differences between the two major Jewish centers in Melbourne and Sydney, as well as the most positive experiences of Australian Jewry as a whole, compared with other parts of the Jewish world. This will be discussed in the next section looking at the evidence of this Australian Jewish experience.

\section{Evidence}

This section will compare and contrast the reactions in the two major Australian Jewish centers: Melbourne and Sydney. It will first provide an overview of the community structures, beginning with the national leadership and then discussing 
Sydney and Melbourne. It will then deal with specific issues relating to the pandemic, including issues relating to caring for the elderly in the community, the impact on religious practice, the move to online activities, the reactions of the haredim (ultra-Orthodox), and how the pandemic impacted on antisemitism in Australia, comparing the two centers where relevant.

\section{Community Structures and Responses}

\section{Reactions at the National Level}

Australian Jewry's national umbrella body, the Executive Council of Australian Jewry (ECAJ), acts as an overall coordinating body. Its leadership rotates every two to three years between Melbourne and Sydney, and in 2020 was Sydney-based. With COVID-19, the leaders in Sydney and Melbourne met to formulate their approach on March 11, the same day as the World Health Organization (WHO) declared the COVID-19 virus outbreak to be a pandemic (Segal 2020). This was followed by a statement issued on March 12 to all 250 Jewish community organizations across Australia, explaining the steps the ECAJ had taken in the face of the pandemic, and encouraging all organizations to follow updates and guidelines from the federal government, as well as their own state, regarding all precautionary steps required. In addition, all community members were asked to report local outbreaks to their local Community Security Group (CSG), or state representative body. The statement stressed that: "Our highest priority is the health and well-being of members of our community. Both individuals and organizations in the community have a shared responsibility to exercise reasonable caution" (ECAJ Statement March 12, 2020). This was publicized in the Jewish media (Australian Jewish News (AJN) March 13, 2020). On March 17, a further statement was issued which stressed:

These are extraordinary times for our community and our nation. We are all living under the strain of upending daily routines, concerns for our loved ones, and a situation that is both uncertain and rapidly evolving (ECAJ Statement, March 13, 2020).

Members of the community were encouraged to look after the most vulnerable, including the elderly, the infirm and the disadvantaged, and these groups were urged to seek assistance, as well as calling for volunteers to come forward, to which there was "a gratifying response" (Segal 2020).

Subsequently, further meetings were held, and additional measures proposed. The ECAJ issued national bulletins, the first two in March, then early April, and for the second wave in August (J-Wire Newsdesk August 28, 2020), to keep the community informed and provide a roundup of developments state by state across the country. Through the collective decisions of the New South Wales Jewish Board of Deputies, led by president Leslie Berger, and the ECAJ, two videos were produced in March, the first featuring Dr. Norman Swan, a Jewish physician, journalist and broadcaster who had migrated to Australia from Scotland and who explained the importance of social distancing (https://www.ecaj.org.au/ 
covid-19-abcs-dr-norman-swan-with-a-special-message-for-the-australian-jewish-community/). The second video message, which ECAJ President Jillian Segal delivered, also stressed the importance of social distancing, especially from grandparents; the need to look after the elderly and vulnerable; and that those in need should reach out for support and counselling (https://www.ecaj.org.au/what-coron avirus-means-for-our-school-kids-seders-and-saftas/).

After the first wave subsided by mid-April 2020, restrictions were eased in the various states, and the federal government released a new COVIDSafe contact app, which the ECAJ welcomed and strongly recommended community members to install it on their phones, even though this was not compulsory. However, the ECAJ also wrote to Prime Minister Morrison, expressing some concerns about privacy, misuse of data, and data security, and making suggestions of various safeguards which the federal government could introduce. With the easing of the lockdown restrictions after the first wave, the Steering Committee became concerned in July that younger members of the community were not taking social distancing seriously because the virus largely affected the elderly. To meet this concern, a third video was produced featuring an interview with Dr. Warren Lee, a fit 50-year-old doctor, who was affected by the virus and told "his harrowing story." The video was posted online https://www.ecaj.org.au/an-australian-doctors-harrowing-covid-19experience/ and it was reported that this video had more than 1.5 million views until November 2020, with mainstream media also featuring it (Segal 2020).

The Jewish communities in each of the Australian states implemented their own emergency arrangements, according to their specific needs, and as with the general community, closed all their offices and moved online as soon as the state government introduced lockdown measures. The states with smaller Jewish communitiesWestern Australia, Queensland, the Australian Capital Territory (ACT), South Australia and Tasmania-experienced very low rates of active cases across the whole period with very few deaths, which as far as is known did not affect anyone in the Jewish community. Members in these communities were encouraged to follow the requirements of their state governments, but overall enjoyed relative flexibility after the first wave when new cases were close to zero.

\section{Sydney Jewish Structure and Responses}

The Sydney Jewish community structure, under the leadership of the New South Wales Jewish Board of Deputies and Jewish Communal Appeal (JCA), reacted quickly to the crisis. The CSG had previously planned for an emergency. Even though the plan was developed more in mind for a security incident or a natural disaster, such as a bushfire, rather than a medical emergency, they were able to adapt quickly to the new situation (Wise interview, October 23, 2020). Initially there was some debate as the members of the Jewish Emergency Management Plan (JEMP) committee came to grips with the situation. CSG chairman Peter Wise explained: "should we be ahead of the curve, should we just be with it or should we be behind it" (Wise interview, October 23, 2020). The Sydney leadership quickly came to a consensus that they should be ahead of the curve and 
established an Emergency Operations Centre, with a central decision-making group, and subcommittees dealing with medical issues, financial support, and mental health, working with the various communal institutions.

JEMP meetings were held regularly-daily at the height of the pandemic with strong coordination and collaboration across Sydney's network of Jewish community organizations. Because of this centralized management structure, the community as a whole, including the synagogues, schools, and other communal institutions, readily accepted the JEMP Committee's decisions. The JCA was able to draw on its resources and it established a Community Support Package of AU\$18 million [US\$13.9 million], including an Emergency Relief Fund of AU\$1 million [US\$77,234.00] which was launched in April and administered by JewishCare NSW. This is not just a huge sum relative to the Melbourne Jewish community, but also relative to most other Jewish communities around the world. The Jewish population in Sydney is just 47,800, but it does reflect the significant wealth within the Sydney Jewish community, as well as the generosity and close coordination of the community.

Many of the applicants were families running small to medium businesses which had been hit hard. These included travel agents, gym owners, and catering companies, which were not the usual group seeking financial assistance. Assistance was generally up to AU\$5000 [US\$3862.00] per family with the offer of ongoing financial counselling. Many were assisted until the federal government income support was implemented through JobKeeper and JobSeeker, but a number continued to have contact with JewishCare NSW, and some have required further assistance (Vernon written communication, October 15, 2020).

The medical subcommittee, chaired by Richard Glass, president of Wolper Jewish Hospital, was initially concerned that there might be insufficient hospital beds for the elderly, and sought to coordinate with hotels to plan for such an emergency. There was also the risk of a shortage of personal protective equipment (PPE), which could have affected the Jewish hospital, Wolper, and the agedcare Montefiore Home facilities. With many GPs no longer having face-to-face consultations, Wolper also coordinated several clinics where older people could come on a weekend or evening knowing they would not have to wait in a crowded waiting room and could receive their flu injections at no charge. Wolper also moved their community health education well-being programs online with their average attendance increasing from an average of up to 150 participants in person to 400-500 online participants, including many suffering from the lockdown in Melbourne. Glass noted that although he suspected that:

... we experienced the same level of medical and mental health issues as the broader community, Jews in need perhaps had more support due to the outreach of JCA, JewishCare, Centre On Ageing (COA) and Jewish House, amongst others, as well as schools providing support for student wellbeing and "child-minding" for parents who had to go to work when the schools were closed down and could not supervise kids at home. (Glass written communication, October 25, 2020) 
He stressed that "we still do not know what the long-term effects in relation to psychological and emotional wellbeing will be... [but] the mental health 'tail' of the pandemic will be a lot longer than that related to physical illness" (Glass written communication, October 25, 2020).

New South Wales with a population of 8.166 million was only slightly affected by the second wave and was able to largely contain the virus with on average fewer than 20 new cases a day in the general population, so that its trajectory was very positive, and synagogues and schools were able to reopen progressively according to state government regulations. With the restricted openings, one challenge that the CSG faced was whether they should police each organization to ensure that the state government regulations were followed, as well as dealing with security issues. The decision was made that it was the responsibility of each organization to ensure that state government regulations were implemented, not the CSG (Wise October 23, 2020).

Overall, as Stephen Chipkin, JCA president, noted: "JCA has the capacity and a relationship with its member organizations to ensure that the network of service providers can continue to meet the needs of the community." JCA has worked on the founding principle that "we need to stand together and that the strong among us needs to support the weaker among us." With the impact of COVID-19, Chipkin and the JCA team ensured that this was their guiding principle, especially as COVID-19 exposed the more vulnerable members of the community: "the impoverished, the mentally stressed, the disabled, the elderly, those people living alone at home needing meals on wheels - there's a lot of support that is needed" (Chipkin interview October 20, 2020). While JCA was prevented from conducting its normal in-person event-driven annual fundraising appeal for the community, Chipkin commented that:

The response of our donors in stepping up to help meet the urgent needs of our community was exceptional and far surpassed expectations. It is a clear reflection of the supportive and collective community we have. (Chipkin interview, October 20, 2020)

\section{Melbourne Jewish Structure and Responses}

In contrast to Sydney, in Melbourne, each organization had to draw on its own resources and undertake their own fundraising. Jewish Community Crisis Management (JCCM), working with the CSG and Hatzolah (Emergency First Responders), established the Victorian Jewish Community COVID-19 Taskforce to coordinate the community response. The Taskforce comprised representatives from JCCM, CSG, Hatzolah, the Jewish Community Council of Victoria (JCCV), Rabbinical Council of Victoria, Progressive Judaism Victoria, and Council of Orthodox Synagogues of Victoria. The Taskforce regularly liaised with Jewish Care Victoria, and other community organizations providing services related to COVID-19. Jewish Care Victoria, which has a wider remit than its sister organization in Sydney, bore the brunt of Melbourne Jewry's response to the pandemic. With its aim to protect all vulnerable members in the community, its CEO Bill Appleby realized that the organization needed increased financial support and, since there is no central fundraising body 
in Melbourne, he took the initiative and approached five key Jewish foundations in Melbourne, receiving a direct subvention from them. He found that by having regular meetings and keeping the foundations informed of exactly what was happening, they became much more engaged, demonstrating that one "needs a strong partnership for philanthropy" (Appleby interview October 22, 2020). In addition, when Jewish Care Victoria held their annual appeal, they set the target of AU\$3.5 million, but exceeded this significantly, raising AU\$4.25 million. For Appleby this represented "the amazing generosity of the community." Facing the many challenges in terms of protecting both clients and staff, as well as working with state government agencies, Appleby found that he had to "politic [sic] very ardently to achieve the best outcome for our organization" (Appleby interview October 22, 2020)—something that was not needed in Sydney because of JCA. A COVID-19 hotline was also organized by Jewish Care Victoria for advice and requests for financial help or other forms of assistance. From its establishment in March 2020 until March 2021 they received 18,000 calls (probably representing a smaller number of people) compared with the normal yearly average of about 6000 out of a community numbering at total of 55,000 .

With the second wave, the number of cases in Victoria began to increase, leading the Victorian government there to introduce stage 3 of the lockdown (closure of pubs, bars, entertainment venues, churches and places of worship, restricting restaurants and cafes to take-away only, and limiting public gatherings to two people) in July on metropolitan Melbourne, where the bulk of the Jewish community reside, and then, on 2 August, declaring the whole of Victoria as a "state of disaster," as well as imposing a full lockdown with stage 4 restrictions in metropolitan Melbourne, including a curfew from $8 \mathrm{pm}$ to $5 \mathrm{am}$, stating that these restrictions would continue for six weeks (JCCV COVID-19 Update \#30, August 3, 2020). After this period, the Victorian government decided to extend the lockdown, with restrictions only being gradually lifted in late October as the number of new infections and deaths plummeted. During the first wave in March and April 2020, Jewish Care Victoria experienced a drop of around $25 \%$ of in-home care hours and had to put staff off, particularly staff coordinating group-based programs that were suspended during stage 4 restrictions. With the second wave from June onwards the numbers returned to pre-COVID-19 numbers because the elderly Jews were isolated for so long, and they also gained more confidence in the system, so Jewish Care Victoria was able to bring more staff back. Their $200+$ field staff also received extra supervision and direction to keep them safe. For Appleby, even with all the extra challenges created by the pandemic, he wanted to ensure that they continued with their longterm strategic planning and positioning of the organization, especially since they had just opened three new facilities, which were part of their strategic plan (Appleby interview October 22, 2020).

Victoria experienced $90 \%$ of the 910 deaths from COVID-19 in Australia and the Victorian state government had to implement what many believed were draconian actions to curb the high infection rates (Victorian Parliamentary Inquiry 2020). The JCCV was very active, issuing regular weekly reports updating its members on the latest state government regulations and advising of support services available. Despite the challenging situation in Melbourne, JCCV Director Judy Fetter 
commented that "the power of community engagement has helped boost people's morale" (Judy Fetter written communication, October 26, 2020).

It is estimated that altogether only about 100 members of the Jewish community have been infected, representing under $0.1 \%$, out of an estimated Jewish population of 118,000, with the only known deaths in the community being in Melbourne (ECAJ Annual Report 2020). As demonstrated by the JPR study, this average of $0.9 \%$ is slightly lower than that of the Australian average of 1.0\% (JPR 2020, p.21). It is much lower than the rate of infections and deaths in the Jewish communities what was designated as Group 1 in the JPR study such as France, the United Kingdom, and the United States (JPR 2020, p. 16), so that Jewish communal organizations were not overwhelmed. The major issue for the Jewish communities going forward will be the significant financial impact on Jewish communal institutions and especially Jewish schools, which will be discussed later.

\section{Specific Issues}

There are several specific issues in terms of communal reactions to the impact of COVID-19. These are discussed in the next section, with the reactions of the Jewish communities of Melbourne and Sydney dealt with separately where relevant.

\section{Caring for the Elderly}

The Australian Jewish community is a comparatively older community, with the median age being 44 in 2016, compared with 38 for the general community (Graham and Narunsky 2020). According to the GEN17 report, the community has relatively high numbers in the older age brackets because of the post-war baby boom (Graham and Markus 2018, p. 10), many of whom are now in the at-risk older age groups. With the first wave, the Jewish aged-care homes in the various Jewish communities introduced strict policies of no visitors, and every effort was made to protect the elderly in their care.

The Situation in Melbourne In Melbourne, following the impact of the second wave and the reintroduction of full lockdown, two Jewish residents died in August, following an outbreak of the virus at the Jewish Care Home in Windsor after a catering contractor tested positive at another aged Jewish facility on July 29. A total of 33 residents and 33 staff members, including agency staff, were infected. A third Jewish resident died in another aged care facility not run by the Jewish community (ECAJ Annual Report 2020).

In a moving article, Melbourne Jewish community activist Abe Schwarz reflected on the challenges of looking after his elderly 91-year-old mother, Tess Schwarz, who was suffering from worsening dementia and was in the Windsor Jewish Care facility in Melbourne. During the first lockdown, in April, this facility moved into a new building, and they managed this transition successfully despite the challenges of Pesach (Passover) and the lockdown. After the lockdown was reintroduced with 
the second wave in Melbourne, Schwarz described the difficult conversation he had with his mother:

When the first lockdown ended, Mum and I were over the moon, as phone calls were replaced by an actual visit. Three more weekly visits were allowed, and then came the dreaded announcement, on July 8, when Jewish Care Victoria halted visiting rights.

I rushed over and saw my mother, the very final visitor to the home. I had to explain, calmly, to this perplexed nonagenarian that "from tomorrow, we can only have phone calls again".

"But why? I haven't done anything! Why are they punishing us??" came her bewildered reply.

Dementia precluded a clear understanding of a pandemic; this was not an easy conversation. But transition to phone calls we did, as Jewish Care maintained zero infections while everyone watched Melbourne's statistics go through the roof. (Schwarz 2020)

When the first COVID-19 case was diagnosed at the Windsor facility in early August, all family members were telephoned and kept informed of further developments. Schwarz's mother was distressed by the "hive of activity" and the fact that she had to remain in her room, including eating her meals there, but the biggest challenge came when she had to be tested. She called her son in distress at the idea of something being stuck up her nose, but, as he described it, "Fortunately, I held her hand down the phone line, and the intrusive swab-testing was done and dusted. Eventually Mum settled, had dinner and went to sleep-soundly, safe and well" (Schwartz 2020).

Despite the tragic loss at the Windsor Home of two elderly Jews, the Jewish aged-care facilities have enjoyed a much better record, with a low mortality rate of $6 \%$, compared with the average mortality rate of $33.5 \%$ across the 220 aged-care facilities in Victoria. Achieving this excellent result was due to several factors. The organization already had good emergency plans in place and never lost control of the situation, as occurred in some other aged-care facilities in both Sydney and Melbourne. In the Jewish Care facilities for the elderly, there was a 72-hour cycle of testing. Appleby described the extent of this undertaking: "[normally] we would generate one wheelie bin of medical waste in a facility per week; with COVID-19 we were generating nearly 100 a week" (Appleby interview October 22, 2020). With the pressures of looking after the homes, Jewish Care organized a lived-in facility for seven weeks catering for staff members who were concerned about their families being affected and who were working 12-hour shifts. Regular meetings were held as well with all seven agencies involved, both Jewish and government in the local area. By advocating strongly with both state and federal government authorities, Appleby was also able to ensure that they received the staff that they needed (Appleby interview October 22, 2020).

In addition, there was the issue of home meal delivery to the elderly members of the Jewish community. Normally, this is mainly provided by elderly volunteers in the community which created a dilemma, as they themselves were more susceptible to the virus. The community leadership turned to the CSG, serviced mainly by 
young volunteers, who were needed less because no synagogue services or other communal events were taking place, so that this younger cohort of volunteers could take over the meal delivery. Elderly Holocaust survivors had special needs in isolation as well, especially in Melbourne, which received the largest number of Holocaust survivors on a pro-rata population basis after Israel. The Jewish Holocaust Centre looked after people in that category, especially elderly folk who have volunteered there as survivor guides.

The Situation in Sydney In contrast to Melbourne, in Sydney in the various locations of the Montefiore facilities for the elderly, no one from either the staff or the residents contracted the virus, and until October 2020, when there were two COVID-related deaths in Melbourne, there were no deaths in these homes. Sydney's Jewish Centre on Ageing (COA), which provides important services for elderly Jews who are still living at home, including delivering meals and helping in other areas, found the demands on its services significantly increased. As in Melbourne, they also called on assistance from the younger community members who volunteered with the CSG.

JewishCare NSW in Sydney also encouraged elderly clients receiving in-home support to replace shopping services with home delivery and cooking services with meals on wheels to minimize contact during lockdown. Virtual programs were introduced across all their services for the elderly, as well as people with disability. They produced a magazine TAKE CARE and included clients of Burger Centre located at the Montefiore Randwick, because it was closed. Their social work team in aged care was particularly focused on families managing someone with dementia at home. JewishCare NSW also continued to provide support for those suffering from mental illness in Sydney, and they found that several people who had previously disengaged from the service returned for assistance as they reported increased sense of stress. They received psychosocial support and, in some cases, required hospital submission. Above all the focus was on the emotional and psychological well-being of all JewishCare NSW's clients (Vernon written communication, October 15, 2020).

\section{Impact on Religious Life}

In his Plus61J editorial published at the end of March, Australian Jewish journalist Michael Visontay noted:

$[F]$ or Jewish communities around the world, the challenge is particularly acute-more than most religions, our Jewishness is predicated on frequent physical communing with family and friends to share life's highs and lows. (March 29, 2020)

Yet, given the Jewish imperative to save lives, the Rabbinical Council of Australia and New Zealand issued a directive in mid-March that all synagogues should suspend social and religious gatherings, including prayer services.

Melbourne Experiences The closure of virtually all Melbourne synagogues, beginning during the first lockdown, was unprecedented in Victoria's history (Kohn 2020a, 
b). With Pesach (Passover), the major family event of the Jewish calendar, occurring shortly after the full lockdown was declared, and all interstate and overseas travel being prohibited, made "the loss to the community particularly powerful" (Stone 2020).

With the onset of the High Holy Days, in Melbourne, where the lockdown was still fully in place, this challenge was even stronger because according to Halakha (Jewish law) Orthodox synagogues are not permitted to offer online services during the main high holy day festival days and no exception was granted in Melbourne. The Rabbinical Council of Victoria organized Project High Holy Days, an initiative comprising on-street shofar sounding, a traditional Jewish practice of blowing the ram's horn, by some 300 volunteers (in which 1491 people took part), so that the shofar was heard across the streets in the city's close-knit community in the southeastern suburbs of St Kilda and Caulfield, as well as other Melbourne suburbs. There were also registered private shofar blowing, care packages, an online Selichot (repentance prayers) event, and other activities (Kohn 2020a, b).

With the partial relaxation of lockdown rules in Melbourne taking effect on September 28 (actually the date of Yom Kippur day), outdoor worship services of no more than five participants and a service leader were permitted. After talks between the Rabbinical Council of Victoria and various state government departments, just before the High Holy Days, some Orthodox synagogues from September 28 onwards began the practice of concurrent outdoor services at their centers, with two physically separate services deemed halachically to constitute a minyan (10 men).

Meanwhile, Progressive Jews took a significantly different path. Temple Beth Israel (TBI), the largest Progressive synagogue in Melbourne, has been conducting online Shabbat and Yom Tov services on YouTube and Facebook for several years, and more recently a daily minyan. But the lockdowns saw some of these innovations expanding to smaller Progressive synagogues in Melbourne. When it became clear that normality would not be returning in time for the High Holy Days, TBI set up its Yachad program and Progressive Judaism Victoria conducted Virtual Mishpacha, a combination of Zoom, YouTube, and Facebook technologies, involving all four Progressive synagogues. The Conservative (Masorti) Kehilat Nitzan synagogue also conducted online religious services, as did Orthodox synagogues, which were of course restricted to pre-Yom Tov and pre-Shabbat time spots (Kohn written communication, October 16, 2020).

Sydney Experiences The situation in Sydney was different to Melbourne since there was only a full lockdown during the first wave of the pandemic in March/April. Restrictions on numbers and requirements to wear a mask were still in place, so that Sydney Jewry still faced challenges, as journalist Gareth Narunsky comments:

We just had new initiatives to bring Yom Tov to people with the "Together Never Apart" initiative, which was fantastic so that people could, you know, feel part of the service from home. At noon on Yom Kippur people were encouraged - wherever they were - to observe a moment of silence. (Interview October 15, 2020) 
Project Shofar was also initiated in Sydney, with rabbis and others going to homes, local parks and communal facilities that were still functioning to blow the shofar.

With the progressive movement, Sydney's Emanuel Synagogue decided that with its 3500 members, it could not guarantee a COVID-safe environment, and the rabbinical leadership was not prepared to decide who could attend, so they only held online services. Richard Glass, chair of Sydney's JEMP medical subcommittee, noted that this:

... opened up a new channel of communication for people to attend services particularly older people who struggle to get to shul and for Jewish people in other parts of New South Wales. (Glass written communication, October 25, 2020)

The broader question for Progressive and Masorti synagogues is how large the online component will figure when times become more "normal" again. While on-line services are seen as a great asset to worshippers who are geographically remote, frail, or ill, the overwhelming aim is still seen as bringing most worshippers physically back into shul (Kohn interview October 15, 2020).

\section{Shift to Online Communal Life}

As with other parts across the Jewish world, the Jewish community in both Melbourne and Sydney adapted quickly to the new situation with most communal activities, such as talks, panel discussions, annual meetings, transferred online via technologies such as Zoom or via live and recorded streaming on YouTube and Facebook. This applied to both Melbourne and Sydney, with many activities becoming national in ways that were not previously possible. As Melbourne journalist, Peter Kohn, pointed out "while this has obvious limits and drawbacks, it also has had the effect of making a far wider range of interesting international speakers available to Australian Jewish participants" (Kohn written comments, October 15, 2020).

All groups also had to transition into working from home, which could be challenging, yet such transitions were managed largely effectively. Commenting on the impact of COVID-19, Gareth Narunsky also noted that:

Another perspective, I guess specific to The Australian Jewish News, is that from late March, most of us were working from home. And our Melbourne team are still working from home... we've never done that before - produced the paper entirely from our living rooms or our bedrooms or our studies. (Interview, October 15, 2020)

The Zionist Federation of Australia organized weekly "Lockdown Learning" sessions, which began with smaller audiences and gradually expanded. ZFA Public Affairs Director Dr. Bren Carlill summed up the significance of the way this was achieved:

It shows the resilience built up through many years of these groups being in existence; if the community didn't have such a strong and long tradition of 
constant gatherings and communal organisation, the resilience and flexibility it showed - enabling it to thrive during the lockdown and physical distancing periods would likely not have occurred. (Bren Carlill written communication, October 22, 2020)

While it is difficult to estimate the full impact of the ZFA Lockdown Learning initiative, it has "kept the community connected to itself and to Israel... Certainly, cumulatively the impact to the community by the efforts of the community has been significant" (Bren Carlill written communication, October 22, 2020).

Jewish schools also had to transfer very quickly to online learning. In Sydney, the schools did this even before it became mandatory with Sydney journalist Gareth Narunsky commenting that "I think all our schools rose to the challenge, amazingly, in that regard" (Narunsky interview October 15, 2020). In Melbourne, it took longer for the schools to implement closure and move to online learning, with only the Yeshivah-Beth Rivkah Colleges closing before the state government mandated closures due to the infection of one of their staff members (ABC News 2020; Lawrence 2020).

One uniquely Australian initiative has been the "Dunera Project." It is named after the infamous ship, the HMT (Hired Military Transport) Dunera, which in 1940 became notorious because of the overcrowding and insufferable conditions experienced by the 2542 men on board, the majority of whom were Jewish internees who were dispatched to Australia due to British fears of their being a "fifth column." Both during their voyage out to Australia and as internees in the Hay and Tatura camps they created facilities where camp inmates could study anything from mathematics to metaphysics and be involved in a range of cultural activities (Patkin 1979; Pearl 1983; Kwiet 1985; Bartorp and Eisen 1990). The Dunera Project has sought to replicate this plethora of cultural and intellectual activities through an online portal. This was the brainchild of Daniel Grynberg, whose parental background of refugee and Holocaust survivor grandparents represents many within the Australian Jewish community and who had worked as a community professional. He described the emergence of the concept as "a crisis response to a crisis situation... born out of just my own personal experience of, I guess, being a bit ahead of the curve" (Grynberg interview October 22, 2020). With the support of the Emanuel Synagogue-which incorporates Reform, Conservative and Renewal Judaism on the one campus-he was able to raise funds and establish the portal.

Originally the idea was just curation and recommendation of different sites. Grynberg established a group of advisers in the different areas of Jewish culture, but they then moved to create their own content as well. Grynberg was also keen to reach out to Melbourne, which is much more culturally active than Sydney Jewry, because for the first time in Australian Jewish history, geography was not so important. Given that Melbourne was still in lockdown, while Sydney was more liberated, they decided to produce the program "To Melbourne With Love," drawing on local talent. The whole show was put together in ten days, largely with "fabulous performers who volunteered pretty much" (Grynberg interview October 22, 2020). Grynberg estimates that around 6500 people would have watched the show. The program also drew in many Israelis, who live in northern New South Wales and are 
largely disconnected from the Jewish community. In this way, the site aims to create a shared space not only between the two major centers, but also for the more isolated Jewish communities across Australia. The focus of the program has been very much on Jewish culture because cultural content is what unites the Jewish people. In this way, it is part of the current Jewish zeitgeist, where cultural Judaism has become the focus of Jewish identity for many Jews (Weissman Joselit 2010).

Whilst on the one hand there has been a plethora of online activities within the Jewish communities of Melbourne and Sydney, on the other hand, most organizations have tended "to consolidate their efforts within their subscribers" (Benjamin interview October 14, 2020), with less local content and particularly local advertising in the two major Australian Jewish media outlets, The Australian Jewish News and J-Wire. Publisher Henry Benjamin expressed the concern: "I think the community has as good as divided itself into even smaller communities and these appear to be functioning very well." However, each organization has become its "own mouthpiece" through their email lists, so that overall "what is happening is that it is consolidating the affiliated but is not reaching out in the same way" (Benjamin interview October 14, 2020). This perhaps reflects the American finding of the Brandeis study that "online Jewish life primarily appealed to those who were most engaged before" (BRJC September 3, 2020, p.15). It is possible, when there is a return to in-person community events, there will be a return to the previous situation, with the added layer of greater on-line participation, and that the Dunera Project, which started out as a reaction to the crisis, will become a feature of Australian Jewish life, strengthening links between Melbourne and Sydney. ZFA CEO Ginette Searle commented: "Emerging into the so-called 'COVID-normal,' the challenge for us is to embrace the innovative ways with which we've been able to grow our engagement and create a hybrid model where on-line connection complements in person events and programs" (Searle written communication, October 22, 2021).

\section{The Ultra-Orthodox (Haredi) Communities}

This was a Melbourne issue because the community there has a small but very active haredi community, which includes a spectrum of different religious affiliations from Adass Israel to Hasidic sects, including Chabad, by far the largest, but also smaller sects such as Gere and Satmar Hasidim. As in other parts of the Jewish world, during Melbourne's first lockdown the claim was made that the Satmar members, concentrated in the Ripponlea area, were holding "prayer meetings in Melbourne this week in defiance of strict social-distancing rules" (Sakkal March 26, 2020b). This created controversy both with the Victorian government and with other members of the Jewish community. Initially, the police were slow to act, but, according to newspaper reports, in April they raided one of these illegal gatherings and fined participants (Sakkal April 9, 2020a), although this report may have been inaccurate. There were also reports in the general press, with the local State MP, David Southwick, stating that it was "appalling that people are not following the rules and putting lives in danger" (Sakkal March 26, 2020b). The chief rabbi of the Adass Israel Congregation, Rabbi Shlomo Kohn, exhorted his congregation to pray at home until the medical advice permitted group prayers. He stressed that "the danger negates the 
requirement to pray with a congregation" (Sakkal March 26, 2020b). The Rabbinical Council of Victoria also issued a statement criticizing the illegal minyanim which put community health at risk. Illegal sederim were also held at Pesach, causing further problems.

With the second lockdown mandated on August 2, 2020, the same group again breached the social distancing rules by holding services with a minyan. The police again raided the prayer group, and their actions were strongly criticized by the Jewish leadership. These meetings later morphed into the practice of claiming minyanim were "support groups" which are permitted under the lockdown regulations, but which the Victorian premier, Daniel Andrews, implied "may be exploiting loopholes" (Kohn August 20, 2020). Further accusations were made in October 2020, but police stated that the services did not violate the coronavirus restrictions (Oster October 13, 2020). Asked by The Australian Jewish News during a media briefing, Premier Daniel Andrews did not mince words about worshippers of any faith using loopholes or otherwise contravening lifesaving COVID-19 regulations. He was quoted extensively in the paper (Kohn August 20, 2020).

One of the security issues that Melbourne CSG has had on its radar are street confrontations, sometimes physical, between worshippers attending minyanim, legal or otherwise, and people confronting them. When this occurred, the local police issued a statement stressing that members of the local Jewish community should not take policing into their own hands-this was the task of the police (Kohn August 7, 2020).

In Sydney, the haredi community is much smaller. Although there were some rumors of illegal minyanim being held, there was no definitive evidence that this was the case. This is another aspect that highlights the differences between the two communities.

\section{Antisemitism}

So far in Australia, the main area of some increase in antisemitism due to COVID19 is among right wing extremists who believe in conspiracy theories and mainly express their views on the social media site, GAB, a site favored by extremists in both Melbourne and Sydney for its free speech policy. Their main theme is that "the Jews are behind coronavirus." As set out in an article in the Times of Israel by Julie Nathan of the ECAJ, their messages focus on global antisemitic tropes and stereotypes, including negative images; the narrative that Jews or the Mossad created the virus; that Jews are deliberately spreading it; it is a plot to take over the world, a Jewish hoax, and/or a money-making scam (Nathan 2020). 


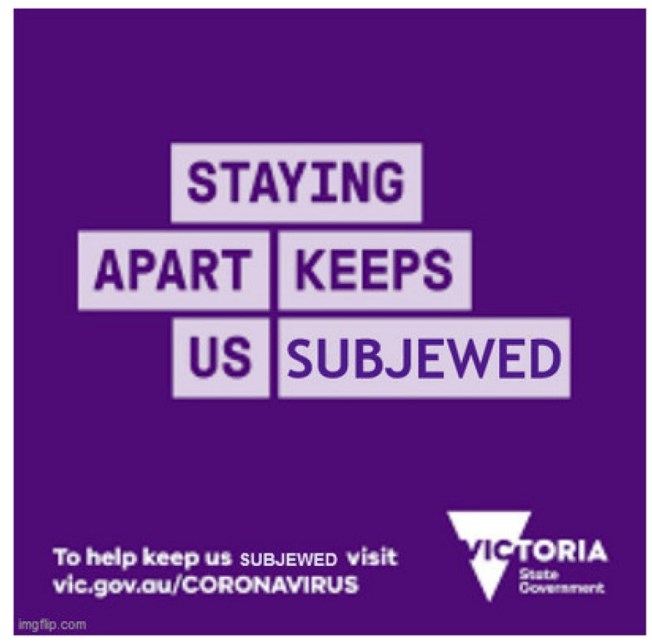

Message from Victorian government photoshopped to change the word "together" to "Subjewed". https://gab.com/system/media_attachments/files/051/752/480/origi nal/77020dd18154fc98.jpg?1588582326.

Accessed October 25, 2020.

The extremists have also targeted Josh Frydenberg, the Melbourne-based Australian Federal Treasurer, especially in relation to his being Jewish. Some of the comments about Frydenberg on GAB mocked the Holocaust, a form of Holocaust distortion:

We have a Jewish Treasurer. Never forget the 6 gorillion stimulus packages https://gab.com/Jamie14/posts/103866475929891039;

Australian FERAL (((treasurer $)))$ - (((frightenedberg $)))$ announced 3rd stimulus package that will help $6,000,000$. Who would have thought that was possible? The Australian Vanguard reposted, https:/gab.com/Zyklon_B/posts/ 103911369372892629; and

6 million. The Jewish Australian Treasurer miraculously uses his powers of gematria to ensure that precisely 6 million Australians get the Shekels. ... Always with the 6 million. No more, no less https:/gab.com/Jamie14/posts/ 103810047394570267.

These attacks are particularly distressing for Frydenberg whose mother is a Hungarian Holocaust survivor. As a result of the threats from the extreme right-wing fringe, he required 24/7 police protection (Zlatkis May 6, 2020). The anti-vaccine campaign also has an antisemitic strand and for religious Christians divine punishment of Jews also features.

So far, this extremist narrative has not gained significant mainstream traction in Australia. At the same time, the threats by the extreme right wing have kept communal organizations busy in both Melbourne and Sydney. Community security has been a top-order issue, and the CSG Victoria has been vigilant in this, working 
closely with Victoria Police and the Jewish community (Kohn written comments, October 15, 2020). Peter Wise, chairman CSG in Sydney explained in relation to these:

... keyboard warriors that hide behind a screen... It is very difficult to assess how much of it is real, how much of it is just rhetoric. But notwithstanding that, you still have to deal with it, and it is a very big part of what CSG does in anticipating future events. It's like being forewarned is forearmed (Wise interview, October 23, 2020).

Thus, again as with other parts of the Jewish world, COVID-19 has kept the CSG's research and analysis departments very busy monitoring the situation, while being faced with the challenge that regular group training is not possible because of social distancing and that they still needed to be ready to respond to an emergency. So, even though there have not been the same security needs when there were no communal gatherings, the threats have not gone away.

\section{Conclusions and Ramifications}

This article has analyzed the impact of COVID-19 on Melbourne and Sydney's Jewish communities from an historical perspective and demonstrated how these communities created structures and sought to transform for greater efficacy. It has also explained the communal decision-making, together with detailed analysis of the pandemic's impact upon community organizations, aged care, and religious institutions. As Claire Vernon, CEO of JewishCare NSW in Sydney, commented:

A crisis like COVID-19 tests the resilience of not just individuals but communities and community organisations. The Jewish community is fortunate to have a network of community organisations like JewishCare which can step up during a crisis. (Vernon written communication, October 15, 2020)

This also applied to JewishCare in Melbourne as seen in the way it was able to successfully step in and deal with the crisis, even though Melbourne was in the eye of the COVID-19 storm. In Melbourne, JCCV Executive Director Judy Fetter commented that:

While the past year has been one of enormous challenges, it has also redefined the central role of the JCCV, helped build resilience, supported the socially isolated and promoted a collaborative approach to sharing information affecting the Victorian Jewish community. (Fetter written communication, October 26, 2020)

Thus, this study reveals that the Australian Jewish community's relatively mild experience of COVID-19, as seen in its low death toll, is attributable to both prudent governmental and communal decision-making, in a milieu of high-level collective trust and compliance, as well as good governance in the Jewish aged care facilities in both cities. 
However, the historical differences between the two major communities impacted on communal decision making and support during the pandemic. Sydney's centralized system of fundraising and communal organization through the Jewish Communal Appeal (JCA) enabled to Sydney Jewish community to respond more quickly, even though the challenges they faced during the second wave of the pandemic were much less than Melbourne because of the differences at the government level. Due to the leadership provided by Jewish Care in Melbourne and actions of the JCCV, the community there did move to a more coordinated approach following Sydney's pattern.

Thus, the impact of COVID-19 has highlighted the need for cooperation and collaboration. Grynberg commented:

I think the lived experience in Sydney of having the JCA, which has existed my whole life, lends us an ability to think in a more collaborative way than Melbourne. So, it is instinctive to me to think in terms of collaboration and platforms. Whereas in Melbourne, I think generally it's harder for them to think that way. I think there are strengths and weaknesses in both. In Melbourne, you know, it generates a lot more entrepreneurialism and innovation, but also, I think it is detrimental competition in a very small marketplace. (Grynberg interview, October 22, 2020)

The Melbourne experience during the pandemic has highlighted the need for greater collaboration, even if it is run on a different model than Sydney's JCA. In the light of his experience of running Jewish Care in Melbourne during the pandemic, Appleby has put together a proposal for greater collaboration entitled "A Case for Change." He argues that just as the crisis of the Six-Day War led to the formation of JCA in 1967, so he hopes the current crisis created by COVID-19 will lead to "an appetite for change" (Appleby interview October 22, 2020). Fetter of the JCCV has also expressed the hope that greater collaboration in Melbourne during the pandemic will lead to "some longer-term mergers resulting in a more rationalised group of organisations to best serve the needs of the Jewish community in the decades ahead" (Fetter written communication October 26, 2020). In this way, Melbourne Jewish communal professionals are seeking to create a transformation in community structures in response to the impact of the pandemic with a more coordinated, permanent approach to fundraising, planning and management, along the lines of the Sydney Jewish community. It remains to be seen if such an approach is implemented.

There is a general feeling that the full financial human impact will only be felt in 2021, and it will be particularly significant in terms of the affordability of the Jewish schools, with more parents being unable to meet the high school fees. The recent Melbourne study of Jewish education (Markus, Munz and Munz 2020) found that the high school fees presented the greatest challenge to parents, and that was before the pandemic. In Sydney, the system was already stretched before the pandemic started, which has only exacerbated the situation. The largest Jewish school, Moriah College, has suddenly another 100 families asking for fee relief-often people who have never needed financial assistance in their lives, and this also applies to the role of JewishCare in Sydney and Melbourne. There is a concern as well about the longterm effects of the trauma of the loss of community on mental health, and whether 
the community will return to the type of large events that it has held in the past, particularly in terms of fundraising. Whilst the major philanthropists and donors have stepped up generosity in the face of the crisis, there is the concern as to whether their level of support can be maintained going forward in the face of the economic downturn. This is a concern facing not only the Australian Jewish community, but the whole Diaspora Jewish world. Thus, the challenge will be how to respond to the aftermath of the crisis, and currently we do not even know when it will be resolved, so we can only develop theories as to what the long-term ramifications will be.

It is also not clear how much longer Australia will be affected by "snap" lockdowns, such as started in Melbourne in May 2021 and has affected much of Australia with the much more infectious Delta variant. Because of the very slow vaccine rollout in Australia, it is being predicted that the full reopening of international borders will not be until mid-2022 or even beyond that time, so that it seems there will be no quick return to life as it was before the pandemic.

These issues require further study, but to date the Australian Jewish community has not invested any resources into a quantitative study of the effects of COVID-19 or its ramifications. Yet, both the Jewish Policy Research Report and the Nishma Research have stressed the importance of such research. This study has been limited by the fact that such research has not been undertaken in Australia and this is an area for future research.

Acknowledgements I would like to thank all the key stakeholders who agreed to be interviewed or who sent written comments for this article and for the written feedback I received. All people named have read their quotations and agreed to the wording.

\section{References}

Bartrop, Paul R., with Eisen, Gabrielle (Eds.). 1990. The Dunera affair: A documentary resource book. Melbourne: The Jewish Museum of Australia and Schwartz and Wilkinson.

ECAJ Statement on Coronavirus (COVID 19) Pandemic, 12 March 2020.

ECAJ. 2020. Community responses to Coronavirus, 17 March 2020.

ECAJ. 2020. Australian Jewish community management of COVID-19 pandemic, National Bulletin \#1, March 20.

ECAJ. 2020. Australian Jewish community management of COVID-19 pandemic, National Bulletin \#2, March 27.

ECAJ. 2020. Australian Jewish community management of COVID-19 pandemic, National Bulletin \#3 April 3.

ECAJ. 2020. Australian Jewish community management of COVID-19 pandemic, National Bulletin \#4, August 28.

ECAJ Media Statement. 2020. COVIDSafe contact app, April 27.

Government and Community Reports and Bulletins

Graham, David, and Andrew Markus. 2018. GEN17 Australian Jewish Community Survey: Preliminary findings. Melbourne: Australian Centre for Jewish Civilisation, Monash University.

Graham, David, and Leon Narunsky. 2020. The Jewish population of New South Wales: Key findings of the 2016 Census. Sydney: JCA.

Joselit Jenna, Weissman. 2010. Culture mavens: Feeling at home in America. In Jews at home: The domestication of identity, ed. Simon J. Bronner, 287-294. London: Littman Library of Jewish Civilisation. 
Kwiet, Konrad. 1985. "Be patient and reasonable!" The internment of German-Jewish Refugees in Australia:On being a German-Jewish Refugee in Australia. Australian Journal of Politics and History 31 (1): 61-77.

Legislative Council, Parliament of Victoria. (2020). Inquiry into the Victorian Government's COVID-19 contact tracing system and testing regime. Melbourne: Victorian Government Printer, December.

Markus, Andrew, Miriam Munz, and Tanya Munz. 2020. GEN 17 Australian Jewish Community Survey: Jewish education in Melbourne. Melbourne: Australian Centre for Jewish Civilisation, Monash University.

Nishma Research. Health, Emotional, Financial \& Religious Impacts of the Coronavirus Pandemic in the Jewish Community. June 10, 2020.

Rutland, Suzanne D. 2005. The Jews in Australia. Melbourne: Cambridge University Press.

Patkin, Benzion. 1979. The Dunera internees. Sydney: Cassell.

Pearl, Cyril. 1983. The Dunera scandal: Deported by mistake. Sydney: Angus and Robertson.

Saxe, Leonard and Krasner Aronson, Janet. 2020. Building resilient Jewish communities: COVID-19 and Jewish community response. BRJC, Brandeis University, September 3 and September 8, https:// www.brandeis.edu/cmjs/research/resilient-communities/index.html. Accessed May 5, 2021.

Segal, Jillian., Wertheim, Peter S., and Ryvchin, Alex. 2020. Letter to the Prime Minister, April 23.

Segal, Jillian. 2020. ECAJ President's Report, ECAJ Annual Report, 2020. Sydney 2020.

Staetsky, L. Daniel. 2021. Elevated Jewish mortality from coronavirus in England and wales: an epidemiological and demographic detective story. Contemporary Jewry. https://doi.org/10.1007/s12397021-09366-2. Accessed 30 April

Staetsky, Daniel. and Paltiel, Ari. 2020. COVID-19 mortality and the Jews: A global overview of the first wave of coronavirus pandemic, March to May 2020, Institute for Jewish Policy Research, December. https://www.jpr.org.uk/searchresults?id=17693andsearchit=COVID-19. Accessed May 2, 2021.

The Victorian Jewish Community COVID-19. 2020. Response: an update by the Victorian Jewish Community Taskforce, Update 30-Information for the Jewish Community on Coronavirus (COVID-19), Victorian Jewish Community COVID-19 Taskforce https://vic.thecsg.org.au/covid-19-communityinformation/. Accessed August 3, 2020.

Trencher, Mark L. 2021. January 18. Ten Months Later-Where Do We Stand? The U.S. Jewish Community's Views on Coronavirus and COVID-19 Vaccines. Nishma Research. http://www.nishmarese arch.com/social-research.html. Accessed May 5, 2021.

\section{Media articles}

Jewish emergency management plan activated. 2020. Australian Jewish News, March 13. https://ajn.times ofisrael.com/ecaj-weighs-in/. Accessed October 15, 2020.

Kohn, Peter. 2020. Suspected COVID breaches: Police "Report, Don't Harass", Australian Jewish News, August 7. https://ajn.timesofisrael.com/police-report-dont-harass/. Accessed October 26, 2020.

Kohn, Peter. 2020. 'Don’t look for loopholes', August 20, https://ajn.timesofisrael.com/health-authoritieswarn-dont-look-for-loopholes/. Accessed October 15, 2020.

Lawrence, Dashiel. 2020. Australian shuls and Jewish schools close, community groups stand up to help. March 19. https://plus61j.net.au/panel1/australian-shuls-jewish-schools-close-community-groupsstand-help/. Accessed 29 March 2020.

Lazarow, Gersh. 2020. A Brave New World. https://www.facebook.com/gersh.lazarow/posts/1015852286 4198956. Accessed 29 October 2020.

Nathan, Julie. 2020. COVID 19 and the plague of online antisemitism, May 26, https://blogs.timesofisr ael.com/covid-19-and-the-plague-of-online-antisemitism/, accessed 27 May 2020.

Nation COVID-19 update. 2020. J-Wire Newsdesk, August 28.

Narunsky, Gareth. 2020. Bringing yom tov to you, Australian Jewish News, September 4. https://ajn. timesofisrael.com/bringing-yom-tov-to-you/. Accessed October 12, 2020.

Oster, Marcey. 2020. Melbourne residents confront Hasidim for allegedly breaking lockdown, 13 October 2020, https://www.timesofisrael.com/writers/marcy-oster/. Accessed April 26, 2021.

Sakkal, Paul. 2020. Police raid ultra-Orthodox prayer group above store in Ripponlea, The Age, April 9. https://www.theage.com.au/national/victoria/police-raid-ultra-orthodox-prayer-group-above-storein-ripponlea-20200409-p54im0.html. Accessed 12 Oct 2020. 
Sakkal, Paul. 2020. Prayer groups defy coronavirus lockdown restrictions, The Age, March 26. https:// www.theage.com.au/national/victoria/prayer-groups-defy-coronavirus-lockdown-restrictions-20200 326-p54e3r.html. Accessed 12 Oct 2020.

Schwarz, Abe. 2020. Caring for my mother in a Melbourne Jewish Care Covid cluster, Plus61J, August 6. https://plus61j.net.au/australia/caring-mother-melbourne-jewish-care-covid-cluster/. Accessed August 7, 2020.

Stone, Deborah. 2020. As soon as it is safe, we will all welcome the return to communality. March 19. https://plus61j.net.au/panel2/soon-safe-will-welcome-return-communality/ Accessed March 29, 2020.

Swan, Norman. and McIntyre, Raina. 2020. How do contact tracing systems differ between NSW and Victoria? Coronacast, ABC radio, October 15. https://www.abc.net.au/radio/programs/coronacast/ how-do-contact-tracing-systems-differ-between-nsw-and-victoria/12767442. Accessed June 27, 2021.

Visontay, Michael. 2020. A letter from the editor of Plus61JMedia to our readers... Plus61J, March 20. https://plus61j.net.au/plus61j-voices/letter-editor-plus61jmedia-readers/. Accessed March 29, 2020.

Yeshivah-Beth Rivkah Colleges closes for 24 hours. 2020. Posted March, 11, https://www.abc.net.au/ news/2020-03-11yeshiva-beth-rivkah-college-coronavirus-closed/12046710?nw=0. Accessed April 26, 2021.

Zlatkis, Evan. 2020. Frydenberg 'targeted by racist extremists'. Australian Jewish News, May 6, https:// ajn.timesofisrael.com/frydenberg-targeted-by-racist-extremists/. Accessed May 27, 2020.

\section{Websites}

"Coronavirus (COVID-19) current situation and case numbers", Australian Government, Department of Health, https://www.health.gov.au/news/health-alerts/novel-coronavirus-2019-ncov-health-alert/ coronavirus-covid-19-current-situation-and-case-numbers. Accessed April 28, 2021.

"Mortality Analysis", John Hopkins University and Medicine, https://coronavirus.jhu.edu/data/mortality. Accessed April 28, 2021.

Publisher's Note Springer Nature remains neutral with regard to jurisdictional claims in published maps and institutional affiliations.

Suzanne D. Rutland (OAM), Her main area of specialization is Australian Jewish history, as well as writing on the Holocaust, Israel and Jewish education. Her latest books are Lone Voice: The Wars of Isi Leibler, and with co-author Zehavit Gross, Special Religious Education and Its Value to Contemporary Society. Her book, co-authored with Sam Lipski, Let My People Go: The Untold Story of Australia and the Soviet Jews, received the 2016 Australian Prime Minister's Literary Award (Australian History). She is a member of the Australian delegation to IHRA. 